\title{
Evaluation of Different Fungicides Against Alternaria Leaf Blight of Tomato (Alternaria solani)
}

\author{
Vijay Kumar*, Gurvinder Singh and Ankur Tyagi \\ Department of Plant Pathology, Dr Y S Parmar University of Horticulture and Forestry, \\ Nauni, Solan (HP)-173230, India \\ *Corresponding author
}

\section{A B S T R A C T}

Keywords

Alternaria blight, Alternaria solani,

Tomato and

Fungicides

Article Info

Accepted:

25 April 2017

Available Online:

10 May 2017
A study on management of Alternaria leaf blight of tomato was carried out in year 2015-2016. Under in vitro evaluation of the botanicals drake (Melia azedarach) has highest efficacy of 63.52 per cent inhibition of the average mycelial growth of the Alternaria solani. However the least effective botanical was Urtica dioica with 36.30 per cent of mycelial inhibition. Among the fungicides most effective was score which inhibit the mycelial growth upto 78.61 per cent followed by 76.67 per cent of carbendazim. Minimum inhibition of the mycelial growth was recorded in kavach $(50.74 \%)$. Under in vivo (pots) evaluation the highest efficacy of score was recorded when sprayed at 0.05 per cent concentration with disease severity of 16.33 per cent and disease control of 74.89 per cent followed by carbendazim fungicide $(18.00 \%, 72.30 \%)$ when compared with control while the least efficacy was observed with the fungicides kavach $(33.67 \%, 48.22 \%)$ and insignia $(26.00 \%$, $60.00 \%)$.

\section{Introduction}

Tomato (Lycopersicon esculentum Mill.) is an important crop grown worldwide and the second most important remunerable solanaceous vegetable crop after potato (Pritesh and Subramanian, 2011; Hadian et al., 2011). It is native to South America and is widely cultivated in 140 countries of the world. Tomato is rich source of Vitamin A, C, $\mathrm{E}$ and good source of antioxidant and contains $95.3 \%$ of water, $0.07 \%$ calcium and niacin, which play importance role in metabolic activities and maintain good human health (Sgherri et al., 2008). China is the rank first in production of tomato followed by India and
USA respectively. In India, tomato cover about 760 thousand hectares with production of 18399 thousand metric tons, mainly grow in Uttar Pradesh, Karnataka, Maharashtra, Haryana, Punjab, Bihar and Himachal Pradesh. In Himachal Pradesh tomato is commercially cultivated in district Bilaspur, Mandi, Solan and Sirmour with production of 430 thousand metric tons and 10370 hectares area (NHB, 2015). Tomato are grown in a wide range of climatic condition, elevation ranging from $1000 \mathrm{M}$ to $2000 \mathrm{M}$ above mean sea level and grow well in a wide range of soil types, which are high in organic matter, 
well-drained and a pH range of 5-7.5. Tomato plants mostly grew well in a wide range of soil types, prefer the well drained and heavily amended with organic matter and should have good moisture retaining capacity (Waiganjo et al., 2006; Robert, 2005).

Tomato crop is vulnerable to bacterial, viral, nematode and fungal diseases. Among the fungal diseases, Alternaria leaf blight of tomato caused by Alternaria solani is the most damaging one that causes reduction in quantity and quality of the tomato crop. Alternaria solani is a soil inhabiting air-borne pathogen responsible for leaf blight, collar and fruit rot of tomato disseminated by fungal spores (Datar and mayee, 1981; Abada et al., 2008). Symptoms of early blight occur on fruit, stem and foliage of tomatoes. Initial symptoms on leaves appear as small 1-2 mm black or brown lesions and under favourable environmental conditions the lesions will enlarge and are often surrounded by a yellow halo. Lesions greater than $10 \mathrm{~mm}$ in diameter often have dark pigmented concentric rings. This so-called "bullseye" type lesion is highly characteristic of early blight. As lesions expand and new lesions develop entire leaves may turn chlorotic and dehisce, leading to significant defoliation. Lesions occurring on stems are often sunken and lens-shaped with a light center, and have the typical concentric rings. On young tomato seedlings lesions may completely girdle the stem, a phase of the disease known as "collar rot," which may lead to reduced plant vigor or death (Gleason and Edmonds, 2006; Kemmitt, 2012). The disease was favored by high temperature and humidity (crowded plantation, high rainfall and extended period of leaf wetness from dew) and plants are more susceptible to the blight infection during fruiting period (Momel and Pemezny, 2006). Present study was aimed to determine the efficacies of different doses of botanicals and fungicides under in vitro and in vivo against Alternaria leaf blight of tomato.

\section{Materials and Methods}

Experiment on the evaluation of different botanicals and fungicides against Alternaria leaf blight of tomato was carried out during 2015-2016 at the vegetable and ornamental laboratory, dept. of Plant Pathology, Dr. Y S Parmar University of Horticulture and Forestry, Solan, Himachal Pradesh, India.

\section{Isolation and identification of Alternaria solani}

The infected plant, showing characteristic symptoms of disease was cut with healthy portion into small pieces $(2-5 \mathrm{~mm})$, surface sterilized with 0.1 per cent sodium hypochloride solution, thrice rinsed with sterilized distilled water and then transferred aseptically on PDA medium in Petri plates. These Petri plates were incubated at $25 \pm 2{ }^{\circ} \mathrm{C}$. After 3 days, a whitish growth of mycelium was observed and a portion from the periphery having single hyphal tip was separated and transferred to other Petri plates having medium to get pure culture and identification of the pathogen was confirmed by observing the morphological features of mycelim. The characteristic feature of genus is the production of beaked, pigmented conidia with relatively thin transverse and longitudinal septa (muriform). The pathogen Alternaria has septate, dark coloured mycelium and produce short, simple, erect conidiophores that bear single and branched chains of conidia in acropetal chains. The pure culture of isolated fungus was maintained in PDA Petri plate kept in refrigerator (Aneja, 2004; Singh, 2009).

In vitro evaluation of botanicals and fungicides against early blight disease of tomato

A total of 6 fungicides and 7 botanicals were evaluated under in vitro conditions against $A$. 
solani through food poisoned technique and using PDA as basal medium. The replication of treatments was done thrice and untreated suitable control was maintained. In vitro evaluation of botanicals was carried out at 10 and 20 per cent and fungicides at four different concentrations viz., 50, 100, 250 and $500 \mathrm{ppm}$. The radial growth of the fungal mycelium was recorded on 10th day when untreated control plates were observed to have maximum growth. The percent inhibition was calculated using the formula.

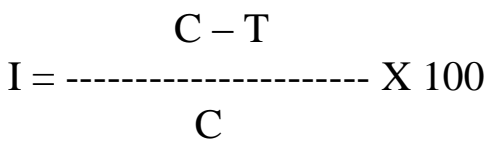

$\mathrm{I}=$ percent inhibition of mycelial growth, $\mathrm{C}=$ radial growth of fungus in control, $\mathrm{T}=$ radial growth of fungus in treatment.

In vivo evaluation of fungicides against early blight disease of tomato

The treatments comprised of application of Antracol (Propineb 70\%), Bavistin (Carbendazim 75\%), Score (Difenoconazole 25\%), Sanit (Metiram 70\%), Kavach (Clorothalonil 75\%) and Insignia (Pyraclostrobin 20\%) and Untreated (control). The disease intensity was recorded on 0-5 scale (Table 1). Five infected plants were selected randomly from each plot and five leaves were selected from each selected plant for scoring the disease intensity data (Singh, 2004). Per cent disease index (PDI) will be calculated by using the formula given by McKinney (1923).

$$
\text { Per cent Disease Index }(\mathrm{PDI})=\frac{\text { Sum of the individual disease ratings }}{\text { Number of leaves observed } X \text { Maximum rating }} \times 100
$$

\section{Statistical analysis}

Statistical analysis was done with using the standard procedure described by Gomez and Gomez (1986).

\section{Results and Discussion}

Present investigation was carried out in pot experiments on "Arka Vikas" cultivar of tomato. The initial symptom (Figure 1) of the disease was observed on the leaves after 60 DAT. Under microscopic examination the causal agent was identified as the Alternaria solani and the figure 2 showed the conidia of the Alternaria solani. The casual agent was isolated from the infected host plant parts and produces bluish to blackish mycelial growth on PDA medium after 7 days of inoculation shown in figure 3 .

In vitro evaluation of the 6 fungicides and 7 botanicals against $A$. solani applying food poisoned technique and using PDA as basal medium were carried out. The data from table 1 revealed that the least average mycelium growth was recorded in treatment amended with lantana (Lantana camara) of $27 \mathrm{~mm}$ followed by the drake (Melia azedarach) (32.00 mm), garlic (Allium sativum) (36.00 $\mathrm{mm})$ and onion (Allium cepa) $(38.00 \mathrm{~mm})$ at 20 per cent concentration while the highest mycelial growth in treatment with Urtica dioica (Stinging nettle) $(60.67 \mathrm{~mm})$ followed by Roylea elegans (Kaddu) $(51.67 \mathrm{~mm})$ and Aonla (Phyllanthus emblica) $(48.67 \mathrm{~mm})$ at 10 per cent concentration. Similarly the highest inhibition of the mycelial growth was found in lantana of 70 per cent followed by the drake $(64.44 \%)$, garlic $(60.00 \%)$ and onion $(57.41 \%)$ at 20 per cent concentration while the lowest mycelial growth in treatment with Urtica dioica (40.00\%) followed by Roylea elegans $(42.59 \%)$ and aonla $(45.93 \%)$ at 10 per cent concentration. Highest mean inhibition of the mycelial growth were found in lantana of 63.52 per cent, drake $(58.89 \%)$ and garlic $(55.37 \%)$ while lowest mean mycelial growth in treatment with Urtica dioica (36.30\%) and Roylea elegans (47.22\%). Raza et al., 2016 studied the effect of botanicals on Alternaria solani under in vitro conditions. 
Table.1 Score of disease intensity of early blight of tomato

\begin{tabular}{|c|c|}
\hline Disease score & Disease severity \\
\hline 0 & No infection \\
\hline 1 & $0.1-1.0$ per cent leaf area affected \\
\hline 2 & $1.1-10.0$ per cent leaf area affected \\
\hline 3 & $10.1-25.0$ per cent leaf area affected \\
\hline 4 & $25.1-50.0$ per cent leaf area affected \\
\hline 5 & $<50.1$ per cent leaf area affected \\
\hline
\end{tabular}

Table.2 In vitro evaluation of botanicals against Alternaria solani

\begin{tabular}{|c|c|c|c|c|c|c|}
\hline \multirow{3}{*}{ Source } & \multirow{2}{*}{\multicolumn{2}{|c|}{$\begin{array}{c}\begin{array}{c}\text { Average mycelial growth } \\
(\mathbf{m m})\end{array} \\
\text { Concentration }(\%)\end{array}$}} & \multirow{3}{*}{ Mean } & $\begin{array}{r}\text { Aver } \\
\text { growth }\end{array}$ & $\begin{array}{l}\text { mycelial } \\
\text { bition }(\%)\end{array}$ & \multirow{3}{*}{ Mean } \\
\hline & & & & \multicolumn{2}{|c|}{ Concentration (\%) } & \\
\hline & 10 & 20 & & 10 & 20 & \\
\hline $\begin{array}{l}\text { Lantana } \\
\text { (Lantana camara) }\end{array}$ & 38.67 & 27.00 & 32.83 & $\begin{array}{l}57.04 \\
(49.03)\end{array}$ & $\begin{array}{l}70.00 \\
(56.77)\end{array}$ & $\begin{array}{l}63.52 \\
(52.90)\end{array}$ \\
\hline $\begin{array}{l}\text { Drake } \\
\text { (Melia azedarach) }\end{array}$ & 42.00 & 32.00 & 37.00 & $\begin{array}{l}53.33 \\
(46.89)\end{array}$ & $\begin{array}{l}64.44 \\
(53.38)\end{array}$ & $\begin{array}{l}58.89 \\
(50.14)\end{array}$ \\
\hline $\begin{array}{l}\text { Garlic } \\
\text { (Allium sativum) }\end{array}$ & 44.33 & 36.00 & 40.17 & $\begin{array}{l}50.74 \\
(45.41) \\
\end{array}$ & $\begin{array}{l}60.00 \\
(50.75) \\
\end{array}$ & $\begin{array}{l}55.37 \\
(48.08) \\
\end{array}$ \\
\hline $\begin{array}{l}\text { Aonla } \\
\text { (Phyllanthus } \\
\text { emblica) }\end{array}$ & 48.67 & 40.67 & 44.67 & $\begin{array}{l}45.93 \\
(42.65)\end{array}$ & $\begin{array}{l}54.82 \\
(47.74)\end{array}$ & $\begin{array}{l}50.37 \\
(45.20)\end{array}$ \\
\hline $\begin{array}{ll}\text { Kaddu } & \text { (Roylea } \\
\text { elegans })\end{array}$ & 51.67 & 43.33 & 47.50 & $\begin{array}{l}42.59 \\
(40.72)\end{array}$ & $\begin{array}{l}51.85 \\
(46.04)\end{array}$ & $\begin{array}{l}47.22 \\
(43.38)\end{array}$ \\
\hline $\begin{array}{l}\text { Stinging nettle } \\
\text { (Urtica dioica) }\end{array}$ & 60.67 & 54.00 & 57.33 & $\begin{array}{l}40.00 \\
(39.22)\end{array}$ & $\begin{array}{l}32.59 \\
(34.80)\end{array}$ & $\begin{array}{l}36.30 \\
(37.01)\end{array}$ \\
\hline Onion (Allium cepa) & 46.00 & 38.33 & 42.17 & $\begin{array}{l}48.89 \\
(44.35)\end{array}$ & $\begin{array}{l}57.41 \\
(49.34)\end{array}$ & $\begin{array}{l}53.15 \\
(46.79)\end{array}$ \\
\hline Control & 90.00 & 90.00 & 90.00 & - & - & - \\
\hline Mean & 51.92 & 46.00 & & $\begin{array}{l}42.32 \\
(38.53)\end{array}$ & $\begin{array}{l}48.89 \\
(42.34)\end{array}$ & \\
\hline C.D. 0.05 & $\begin{array}{l}\text { Treatme } \\
\text { Concent } \\
\text { Treatme } \\
\text { Concent }\end{array}$ & $\begin{array}{c}=1.44 \\
(\mathrm{C})=0.72 \\
(\mathrm{~T}) \\
(\mathrm{C})=2.03\end{array}$ & & $\begin{array}{l}\text { Treatme } \\
\text { Concent } \\
\text { Treatme } \\
\text { Concent }\end{array}$ & $\begin{array}{l}=0.93 \\
(\mathrm{C})=0.47 \\
(\mathrm{~T}) \quad \mathrm{X} \\
(\mathrm{C})=1.32\end{array}$ & \\
\hline
\end{tabular}


Table.3 In vitro evaluation of fungicides against Alternaria solani

\begin{tabular}{|c|c|c|c|c|c|c|c|c|c|c|}
\hline \multirow{3}{*}{ Treatment } & \multirow{2}{*}{\multicolumn{4}{|c|}{$\begin{array}{c}\text { Average mycelial growth }(\mathbf{m m}) \\
\text { Concentration }(\%)\end{array}$}} & \multirow{3}{*}{ Mean } & \multirow{2}{*}{\multicolumn{4}{|c|}{$\begin{array}{c}\text { Average mycelial growth inhibition } \\
(\%)\end{array}$}} & \multirow{3}{*}{ Mean } \\
\hline & & & & & & & & & & \\
\hline & 50 & 100 & 250 & 500 & & 50 & 100 & 250 & 500 & \\
\hline Antracol & 50.00 & 38.33 & 29.33 & 16.67 & 33.58 & $\begin{array}{l}44.44 \\
(41.79)\end{array}$ & \begin{tabular}{|l|}
57.41 \\
$(49.24)$
\end{tabular} & $\begin{array}{l}67.41 \\
(55.17)\end{array}$ & $\begin{array}{l}81.48 \\
(64.50)\end{array}$ & $\begin{array}{l}62.69 \\
(52.68)\end{array}$ \\
\hline Carbundazim & 37.00 & 28.00 & 19.00 & 0.00 & 21.00 & $\begin{array}{l}58.89 \\
(50.10)\end{array}$ & \begin{tabular}{|l|}
68.89 \\
$(56.09)$
\end{tabular} & $\begin{array}{l}78.89 \\
(62.63)\end{array}$ & $\begin{array}{l}100.00 \\
(88.15)\end{array}$ & $\begin{array}{l}76.67 \\
(633.91)\end{array}$ \\
\hline Insignia & 58.67 & 44.67 & 37.67 & 22.33 & 40.83 & $\begin{array}{l}34.82 \\
(36.14)\end{array}$ & \begin{tabular}{|l|}
50.37 \\
$(45.19)$
\end{tabular} & $\begin{array}{l}58.15 \\
(49.67)\end{array}$ & $\begin{array}{l}75.19 \\
(60.10)\end{array}$ & $\begin{array}{l}54.63 \\
(47.78)\end{array}$ \\
\hline Sanit & 58.00 & 42.67 & 34.33 & 21.00 & 39.00 & $\begin{array}{l}35.56 \\
(36.58)\end{array}$ & \begin{tabular}{|l|}
52.59 \\
$(46.47)$
\end{tabular} & $\begin{array}{l}61.85 \\
(51.83)\end{array}$ & $\begin{array}{l}76.67 \\
(61.10)\end{array}$ & $\begin{array}{l}56.67 \\
(49.00)\end{array}$ \\
\hline Kavach & 62.00 & 47.67 & 40.33 & 27.33 & 44.33 & $\begin{array}{l}31.11 \\
(33.88)\end{array}$ & \begin{tabular}{|l|}
47.04 \\
$(43.29)$
\end{tabular} & $\begin{array}{l}55.19 \\
(47.96)\end{array}$ & $\begin{array}{l}69.63 \\
(56.54)\end{array}$ & $\begin{array}{l}50.74 \\
(45.42)\end{array}$ \\
\hline Score & 35.33 & 25.00 & 16.67 & 0.00 & 19.25 & $\begin{array}{l}60.74 \\
(51.19)\end{array}$ & \begin{tabular}{|l|}
72.22 \\
$(58.17)$
\end{tabular} & $\begin{array}{l}81.48 \\
(64.50)\end{array}$ & $\begin{array}{l}100.00 \\
(88.15)\end{array}$ & $\begin{array}{l}78.61 \\
(65 . .50)\end{array}$ \\
\hline Control & 90.00 & 90.00 & 90.00 & 90.00 & 90.00 & - & - & - & - & - \\
\hline Mean & 55.86 & 45.19 & 38.19 & 25.33 & & $\begin{array}{l}37.94 \\
(35.67)\end{array}$ & \begin{tabular}{|l|}
49.79 \\
$(42.63)$
\end{tabular} & $\begin{array}{l}57.57 \\
(47.40)\end{array}$ & $\begin{array}{l}71.85 \\
(59.61)\end{array}$ & 62.69 \\
\hline C.D. 0.05 & $\begin{array}{l}\text { Treatme } \\
\text { Concent } \\
\text { (C) }=0.7^{\circ} \\
\text { Treatme } \\
\text { Concent } \\
(\mathrm{C})=2.0\end{array}$ & $\begin{array}{l}=1.01 \\
\text { (T) } \mathrm{x}\end{array}$ & & & & $\begin{array}{l}\text { Treatme } \\
\text { Concent } \\
\text { Treatme } \\
\text { Concent }\end{array}$ & $\begin{array}{l}\text { nt }(\mathrm{T})=0.7 \\
\text { ration }(\mathrm{C})= \\
\text { nts } \\
\text { ration }(\mathrm{C})=\end{array}$ & $\begin{array}{l}.59 \\
.56\end{array}$ & & \\
\hline
\end{tabular}

Table.4 In vivo evaluation of fungicides against early blight disease of tomato

\begin{tabular}{|l|c|c|c|}
\hline Treatment & Concentaration (\%) & Diseases Severity (\%) & Diseases control (\%) \\
\hline Antracol & 0.25 & $20.33(26.79)$ & $68.71(55.97)$ \\
\hline Carbandazim & 0.10 & $18.00(25.09)$ & $72.30(58.23)$ \\
\hline Insignia & 0.05 & $26.00(30.64)$ & $60.00(50.75)$ \\
\hline Sanit & 0.30 & $23.33(28.69)$ & $64.12(53.18)$ \\
\hline Kavach & 0.20 & $33.67(35.45)$ & $48.22(43.96)$ \\
\hline Score & 0.05 & $16.33(23.81)$ & $74.89(43.96)$ \\
\hline Control & - & $65.00(53.71)$ & - \\
\hline C.D. 0.05 & & 2.04 & 2.51 \\
\hline
\end{tabular}


Figure.1 Initial symptoms of Alternaria solani on tomato leaf

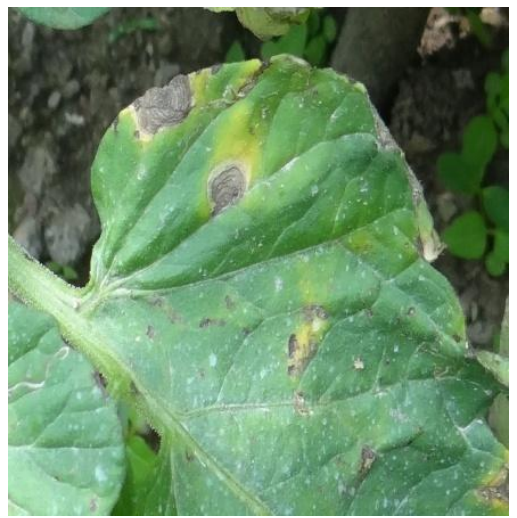

Figure.2 Pure culture of the Alternaria solani

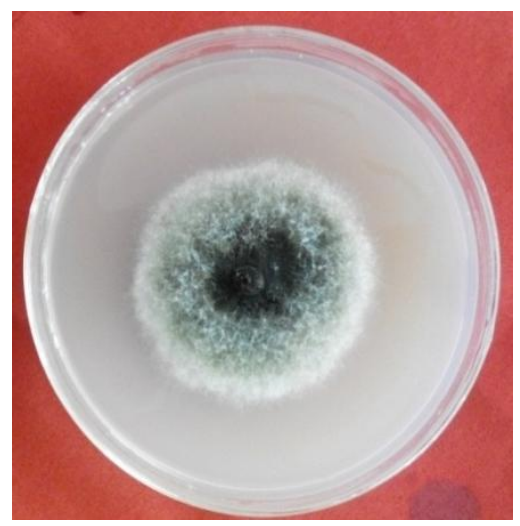

Figure.3 Conidia of Alternaria solani

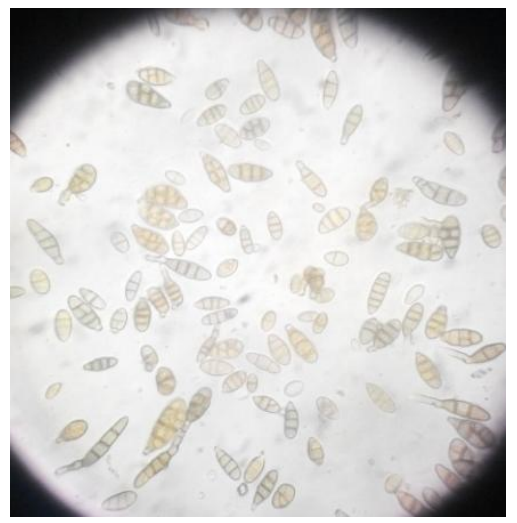


Data on in vitro evaluation presented in table 2 revealed that most effective fungicide was carbendazim and score at $500 \mathrm{ppm}$ where no growth of fungus mycelium and 100 per cent inhibition of the fungus was recorded followed by the antracol (16.67 mm, 81.48\%). While the highest growth and least inhibition was observed at the $50 \mathrm{ppm}$ with treatments amended with kavach (62.00 mm 31.11\%), insignia (58.57 mm, 34.825) and Sanit (58.00, $35.56 \%$ ). Highest mean mycelial inhibition was recorded in treatment with score (78.61\%), carbendazim $(76.67 \%)$ and antracol $(62.69 \%)$ while least was observed in kavach (50.74\%), Insignia (54.63\%) and sanit $(56.67 \%)$. These results were in collaboration with the Chohan et al., (2015) and Gazanafar et al., (2016) who studied the effect of different fungicides under in vitro conditions.

A pot trail was conducted under in vivo condition for the evaluation of fungicide which was used under in vitro conditions. Perusal of data from the table 3 revealed that the highest efficacy of the score was recorded when sprayed at 0.05 per cent concentration with disease severity of 16.33 per cent and disease control of 74.89 per cent when compared with control. Next best efficacy was recorded with carbendazim fungicide (18.00\%, 72.30\%), antracol (20.33\%, $68.71 \%)$ and sanit $(23.33 \%, 64.12 \%)$ while the least efficacy was observed with the fungicides kavach $(33.67 \%, 48.22 \%)$ and insignia $(26.00 \%, 60.00 \%)$. Similar results were recorded by Sahu et al., (2013), Chohan et al., (2015), Neesha et al., (2015) and Soni et al., (2015) while studying the efficacy of fungicides under field conditions.

\section{References}

Abada, K.A., S.H. Mostafa, Hillal and Mervat, R. 2008. Effect of some chemical salts on suppressing the infection by early blight disease of tomato. Egypt J. Appl. Sci., 23: 47-58.
Aneja, K.R. 2004. Experiment in microbiology, Plant pathology and bacteriology (4th Ed). New age International $P$ (Ltd). Publisher, NEW DELHI, INDIA.

Chohan, S., R. Perveen, M.A. Mehmood, S. Naz, and Akram, N. 2015. Morphophysiological studies, management and Screening of Tomato Germplasm against Alternaria solani, the causal agent of tomato early blight. Int. J. Agri. Biol., 17(1): 111-118.

Datar, V.V., and Mayee, C.D. 1981. Assessment of loss in tomato yield due to early blight. Indian Phytopathol., 34: 191195.

Ghazanfar, M.U., W. Raza, K.S. Ahmed, M.H. Rasheed, J. Qamar and Haider, N. 2016. Evaluation of different fungicides against Alternaria solani (Ellis \& Martin) Sorauer cause of early blight of tomato under laboratory conditions. Int. J. Zool. Studies, 1(5): 8-12.

Gleason, M.L., and Edmonds, B.A. 2006. Tomato diseases and disorders, 12661277.

Gomez, K.A., and Gomez, A.A. 1986. Statistical procedures for agriculture research. 2nd edition, John Wiley and Sons, 680p.

Hadian, S., K. Rahnama, S. Jamali and Eskandari, A. 2011. Comparing neem extract with chemical control on Fusarium oxysporum and Meloidogyne incognita complex of tomato. $A d v$. Environ. Biol., 5(8): 2052-2057.

Kemmitt, G. 2002. Early blight of potato and tomato. The Plant Health Instructor. DOI: 10.1094/PHI-I-2002-0809-01 Updated 2013.

McKinney, H.H. 1923. Influence of soil temperature and moisture on infection of wheat seedlings by Helminthosporium sativum. J. Agri. Res., 26: 195-217.

Momel, T.M., and Pemezny, K.L. 2006. Florida plant disease management guide: Tomato. Florida Cooperation Extensive Service, Institute of Food and Agriculture Sciences. $\quad 134 . \quad$ NHB. 2015. http://nhb.gov.in 
Neesha, T., G. Akhtar, S. Khan, J. Zobia, H.M. Anwar and Khan, A. 2015. In vivo assessment of efficacy of different fungicides for control of early blight of tomato. Int. J. Life Sci., 9(1-4): 32573263.

Pritesh, P., and Subramanian, R.B. 2011. PCR based method for testing Fusarium wilt resistance of tomato. African J. Basic and Appl. Sci., 3(5): 222-227.

Raza, W., M.U. Ghazanfar, Y. Iftikhar, M.H. Rasheed, K.S. Ahmed and Haider, N. 2016. Management of early blight of tomato through the use of plant extracts. Int. J. Zool. Studies, 1(5): 1-4.

Robert, R.W. 2005. Growing tomatoes. University of Georgia College of Agricultural. \& Environal Science Bulletin, 3(2): 487- 488 .

Sahu, D.K., C.P. Khare, H.K. Singh and Thakur, M.P. 2013. Evaluation of newer fungicide for management of early blight of tomato in chhattisgarh. The bioscan, 8(4): 1255-1259.
Sgherri C., Z. Kadlecova, A. Pardossi, F Navari-Izzo and Izzo, R. 2008. Irrigation with diluted seawater improves the nutritional value of cherry tomatoes. $J$. Agri. Food Chem., 56: 3391-3397.

Singh, R.S. 2009. Plant Diseases, Ninth edition, Oxford and IBH Publishing Pvt. Ltd., New Delhi, pp: 388-389.

Singh, R.S. 2004. Introduction to Principles of Plant Pathology, fourth edition, Oxford and IBH Publication, Pvt. Ltd., NEW Delhi, India.

Soni, R., R.N. Bunker, U.K. Dhakad and Yadav, A. 2015. Efficacy of fungicide, botanical and bionanoformulation for suppression of early blight of tomato caused by Alternaria solani. The Ecoscan, 8: 337-340.

Waiganjo, M.M., N.M. Wabule, D. Nyongesa, J.M. Kibaki, I. Onyango, S.B. Webukhulu and Muthoka, N.M. 2006. Tomato production in Kirinyaga District, Kenya. A baseline survey report. KARI/IPMCRSP Collaborative project. http:// www.learningace.com.

\section{How to cite this article:}

Vijay Kumar, Gurvinder Singh and Ankur Tyagi. 2017. Evaluation of Different Fungicides Against Alternaria Leaf Blight of Tomato (Alternaria solani). Int.J.Curr.Microbiol.App.Sci. 6(5): 23432350. doi: https://doi.org/10.20546/ijcmas.2017.605.262 